\title{
Phenology and sex ratio of the parasitoids of a cereal leaf miner Chromatomyia fuscula (Diptera: Agromyzidae)
}

\author{
ELINE B. HÅGVAR ${ }^{1}$, NiNA TRANDEM ${ }^{2}$ and TROND HOFSVANG ${ }^{2}$ \\ ${ }^{1}$ Department of Biology and Nature Conservation, Agricultural University of Norway, P.O. Box 5014, N-1432 As, Norway; \\ e-mail: eline.hagvar@ibn.nlh.no \\ ${ }^{2}$ Department of Entomology and Nematology, Plant Protection Centre, The Norwegian Crop Research Institute, Høgskoleveien 7 , \\ N-1432 Ås, Norway
}

Key words. Agromyzidae, Chromatomyia fuscula, Chalcidoidea, Cyrtogaster vulgaris, Diglyphus begini, leaf miner, barley, boundary, Malaise, parasitoid, phenology, sex ratio

\begin{abstract}
The univoltine leaf miner Chromatomyia fuscula Zetterstedt is a Scandinavian cereal pest. We wanted to compare the phenology of C. fuscula in southern Norway with that of its most important natural enemies: 15 parasitoids of the families Eulophidae and Pteromalidae (Hymenoptera: Chalcidoidea). The use of two Malaise traps in an organically-grown spring barley field and its boundary through 6 seasons (1992-1997) also allowed us to compare these two habitats and to observe the effect of harvesting on the parasitoid activity without interference from pesticides. C. fuscula overwinters as an adult and oviposits in May/June. Few specimens of the next generation, emerging in the crop, were caught in the boundary traps, suggesting the fly hibernates elsewhere. In contrast, the $F_{1}$ generation of the parasitoids was caught in considerable amounts both in the crop and boundary. The abundance of parasitoids was highest in July/August; in the crop it usually started decreasing well before harvesting; in the boundary it peaked two weeks or more after harvesting. The results suggest that many parasitoids (especially females) move from the crop to the boundary (or beyond) before harvesting. In both habitats parasitoid species richness usually increased until harvesting, and thereafter decreased. The pooled parasitoid female proportion was 0.36 ; in crop and boundary it was 0.30 and 0.66 , respectively, and the majority of species had a higher proportion of females in the boundary than in the crop. The phenology of two of the most common parasitoids is presented: The pupal parasitoid Cyrtogaster vulgaris Walker (Pteromalidae) had a high activity in the boundary, also very early (females only) and late (both sexes) in the season. The larval parasitoid Diglyphus begini (Ashmead) (Eulophidae) was less active early and late in the season, and had a much smaller boundary activity than C. vulgaris. Both sexes were present throughout the season. The annual sex ratio of $D$. begini was density dependent, being highly male biased in the two years with highest catches. In C. vulgaris neither density nor habitat explained the sex ratio. D. begini probably overwinters inside the mine as a preadult, having one generation on C. fuscula in the crop and another one in an alternate host away from the habitats sampled here. C. vulgaris overwinters as fertilized females in the border habitat.
\end{abstract}

\section{INTRODUCTION}

The leaf miner Chromatomyia fuscula (Zetterstedt) is a regular pest of cereals in Scandinavia (Andersen, 1991). It is univoltine and overwinters as an adult, probably out of arable fields (Andersen, 1991, pers. comm.). In a seven-year project we studied C. fuscula and its parasitoid complex in an organically-grown spring barley field in southern Norway. Barley is the most important cereal in Norway, and is often heavily attacked by C. fuscula. The project is described in Hågvar et al. (1998), who also presented the annual total Malaise catches of the adult leaf miner and 15 of its parasitoids over a period of six years, plus the annual composition of the parasitoid complex in the barley crop and its boundary.

In the present paper, we use the Malaise data to study the phenology of the leaf miner and its parasitoids (Hymenoptera: Chalcidoidea) in the two habitats. The questions asked at the outset were: (1) How does the phenology of the parasitoids relate to the phenology of $C$. fuscula, and are there any differences between the field and the boundary? (2) Does harvesting affect the parasitoid population ? (3) How does the sex ratio of important parasitoids vary through the season in the two habitats?
The answers to these questions are important to understand the biology of the parasitoids and their interactions with C. fuscula, and ultimately, why C. fuscula is a pest. The answers may also contribute to a better understanding of how to preserve and enhance natural enemies of pests in general (Barbosa, 1998). In this context, the function of boundary habitat has received considerable attention (e.g. in Altieri, 1994; Ekbom et al., 2000), but the effect of harvest on the beneficial fauna is less studied, and we are not aware of any previous work on the effect of harvesting on adult parasitoid populations in cereals.

\section{MATERIAL AND METHODS}

Two black Malaise traps ("Museum" type collecting head) sampled flying insects continuously from the barley crop and its forested boundary, respectively, during the season in 1992-1997 (no boundary trap in 1994). The collecting bottles (with $70 \%$ alcohol) were emptied about once a week, and C. fuscula and 15 species of chalcidoid parasitoids were sorted out. These species had been reared from C. fuscula mines in the area (Hågvar et al., 1994), and made up the majority of parasitoids attacking $C$. fuscula in Norway, although none of them has C. fuscula as their only host (Trandem, 1998; see also Hågvar et al., 1998 and 
Darvas et al., 1999). A total of 51,600 specimens were sorted out, including the host C. fuscula ( $22 \%$ of the catches). C. fuscula pupates in the mine, and the parasitoids were larval, larvalpupal and pupal, all of them solitary (i.e. producing one progeny per host).

The crop trap sampled for a shorter period (usually from May to harvest in August/September, but continuing after the harvest in 1996 and 1997) than the boundary trap (usually May to October/November); exact periods are given in Table $2^{*}$ in Hågvar et al. (1998). The barley crop made up one sixth of a 15.5 ha field with crop rotation; therefore both traps changed positions every year, the crop trap being placed about $60 \mathrm{~m}$ from the forested boundary of that year's barley field (see Hågvar et al., 1998, for a map). In 1995 and 1997 the boundary trap was placed in a $2-5 \mathrm{~m}$ broad strip with semi-natural grass and herb vegetation between the eastern part of the field and the forest. In the other years, the boundary trap was placed among the bordering trees of the forest south of the field (with a ditch and narrow grassy strip separating it from the crop). Mines of $C$. fuscula and other leaf miners were present in the grass along the field, but in much smaller numbers than in the crop. Weather data were available from a station about one $\mathrm{km}$ south of the field, and relevant monthly temperatures and precipitation for all six years are given in Hågvar et al. (1998).

\section{RESULTS AND DISCUSSION}

\section{Phenology of $C$. fuscula}

The parent generation $\left(\mathrm{F}_{0}\right)$ of adult $C$. fuscula came into the crop and was very active from the last weeks of May to about middle of June. Later in the season few flies were sampled, except in 1993 and 1997, when a distinct second generation $\left(F_{1}\right)$ was caught (Fig. 1). In the other 4 years, a high preadult mortality was observed (see Hågvar et al., 1998). The weekly catch of $F_{1}$ in the crop peaked 6 weeks after $F_{0}$ in 1993 and 5 weeks later in 1997 (Fig. 1), the time lags roughly corresponding to the development time of $C$. fuscula at constant temperatures of 12 and $15^{\circ} \mathrm{C}$, respectively (44 and 35 days, or 424 and 402 degree-days; Andersen \& Fugleberg, 1997). These temperatures are somewhat lower than the average monthly temperatures in June and July in the present study: $13-15^{\circ} \mathrm{C}$ in 1993 and $16-18^{\circ} \mathrm{C}$ in 1997.

In the boundary, relatively few flies were caught, usually with no distinct peaks (in contrast to the crop). Even when $F_{1}$ emergence was high (1993 and 1997), the boundary catches were poor. Assuming that the traps collected flies active in the nearby vegetation throughout the season, as they apparently did during the oviposition period in the crop, the flies did not seem to use the boundary for overwintering or foraging. The capture height of the Malaise traps was only $1 \mathrm{~m}$, so if the flies were not using the boundary, they would have no difficulties in flying above the traps. A. Andersen (pers. comm.) confirms that although the overwintering habitat for $C$. fuscula is still largely unknown, the majority of flies invading the crop in spring do not come from the near boundary.

\section{Phenology of the parasitoids: abundance and species richness}

Parasitoids were present in the catches from the time the traps were set up in April-May until they were removed in October-November (when normal average monthly temperature at the locality is $0.4^{\circ} \mathrm{C}$ ), but not all species were present for the whole trapping period (Table 1 ), and the number of individuals early and late in the season was usually low (Fig. 1). Table 1 gives the complete parasitoid list, showing their average monthly presence in the catches (for more information on their biology, see Trandem, 1998). They are sorted in order of first appearance each year and this order is obviously influenced by how common a species is, because (other things being equal) an abundant species will have a higher probability being trapped early than a rare species (C. vulgaris and D. begini at the top of the list confirm
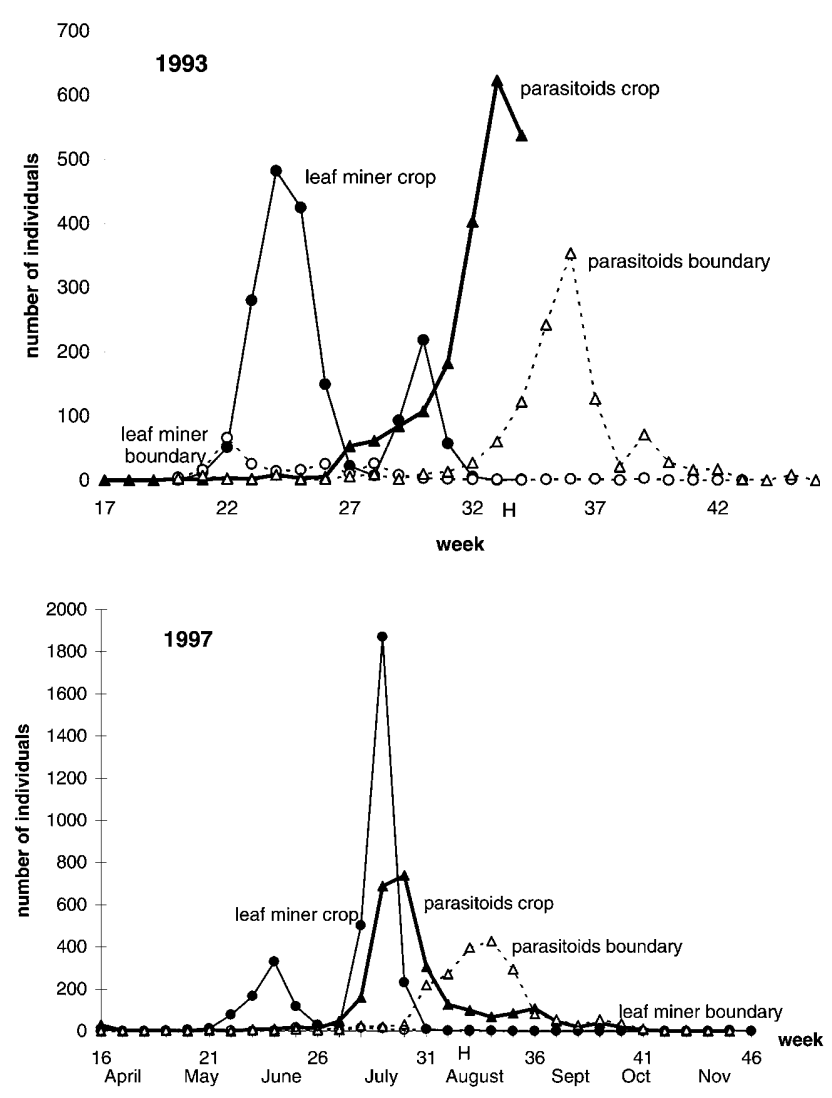

Fig. 1. Phenology of Malaise catches in crop and boundary for C. fuscula and its parasitoids (15 species) in 1993 and 1997. $\mathrm{H}$ - harvest.

this). However, abundance alone cannot explain the order in Table 1, as some rare species appeared earliest in the season and vice versa. Table 1 therefore reflects differences in phenology as well as in abundance.

The parasitoid abundance, measured as total weekly parasitoid catch, was usually at its highest in July-August in both habitats (Fig. 1). In the crop, parasitoid catches

\footnotetext{
* Error in this table: read 8.11 instead of 15.10 in 1996 (both crop and boundary).
} 
usually peaked 5 to 9 weeks after the $F_{0}$ generation of C. fuscula. In the two years with a distinct $F_{1}$ C. fuscula generation, parasitoid catches in the crop peaked 3 (1993) and 1 (1997) week after the $F_{1}$ flies (as noted above, 1997 was warmer than 1993). Thus, the parasitoid peak in the crop catches probably consisted of individuals that developed on the progeny of $\mathrm{F}_{0}$ C. fuscula (Hågvar et al., 1998). In contrast to the $C$. fuscula catches, the parasitoid catches also had a clear abundance peak in the boundary. This occurred later than the peak in the crop in 4 of the 5 years with trapping in both habitats (illustrated for two years in Fig. 1), the lag being 1-4 weeks. The considerable catches in the boundary suggest that the parasitoids use the boundary to a much larger extent than their host C. fuscula. We will return to this point later.

Although the total annual number of parasitoid species caught in the two habitats was similar (Hågvar et al., 1998), the weekly species number in general was higher, and peaked earlier, in the crop than in the boundary (Fig. 2 ). The difference in weekly species numbers may partly be explained by the usually higher number of individuals trapped per week in the crop than in the boundary (c.f. Fig. 1), since species number increased with number of specimens up to a certain level (Fig. 3). The maximum species richness in the crop always occurred in July or August (range: week 28-34), and in the boundary in July, August or September (range: week 26-36).

Darvas et al. (1999) reared C. fuscula and its parasitoids during a six-week study in 1992 in two Norwegian barley fields, one of them only $1 \mathrm{~km}$ from our field. That year had an unusually warm and dry May and June, and was not representative for our study period (1991-97) (Hågvar et al., 1998). The general flight periods given by Darvas et al. (1999) are based on literature from other countries and may be unreliable for Norway. However, taking into account the effect of latitude, the periods given in Darvas et al. (1999) accord fairly well with our data, except for Neochrysocharis aratus, which had a longer activity period in our study (Table 1).

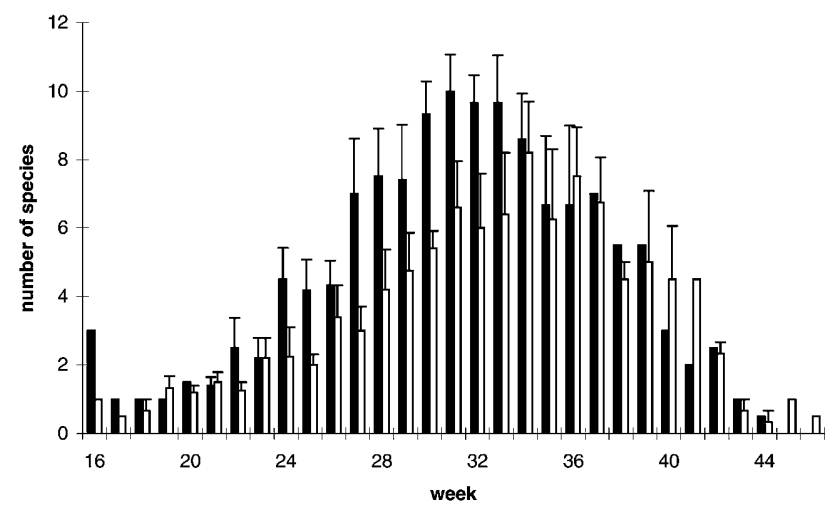

Fig. 2. Number of C. fuscula parasitoid species in Malaise catches from the crop (filled columns) and boundary (open columns). Average of weekly catches (1992-97), 15 species included. Vertical lines - SE, only calculated when data available for more than two years.
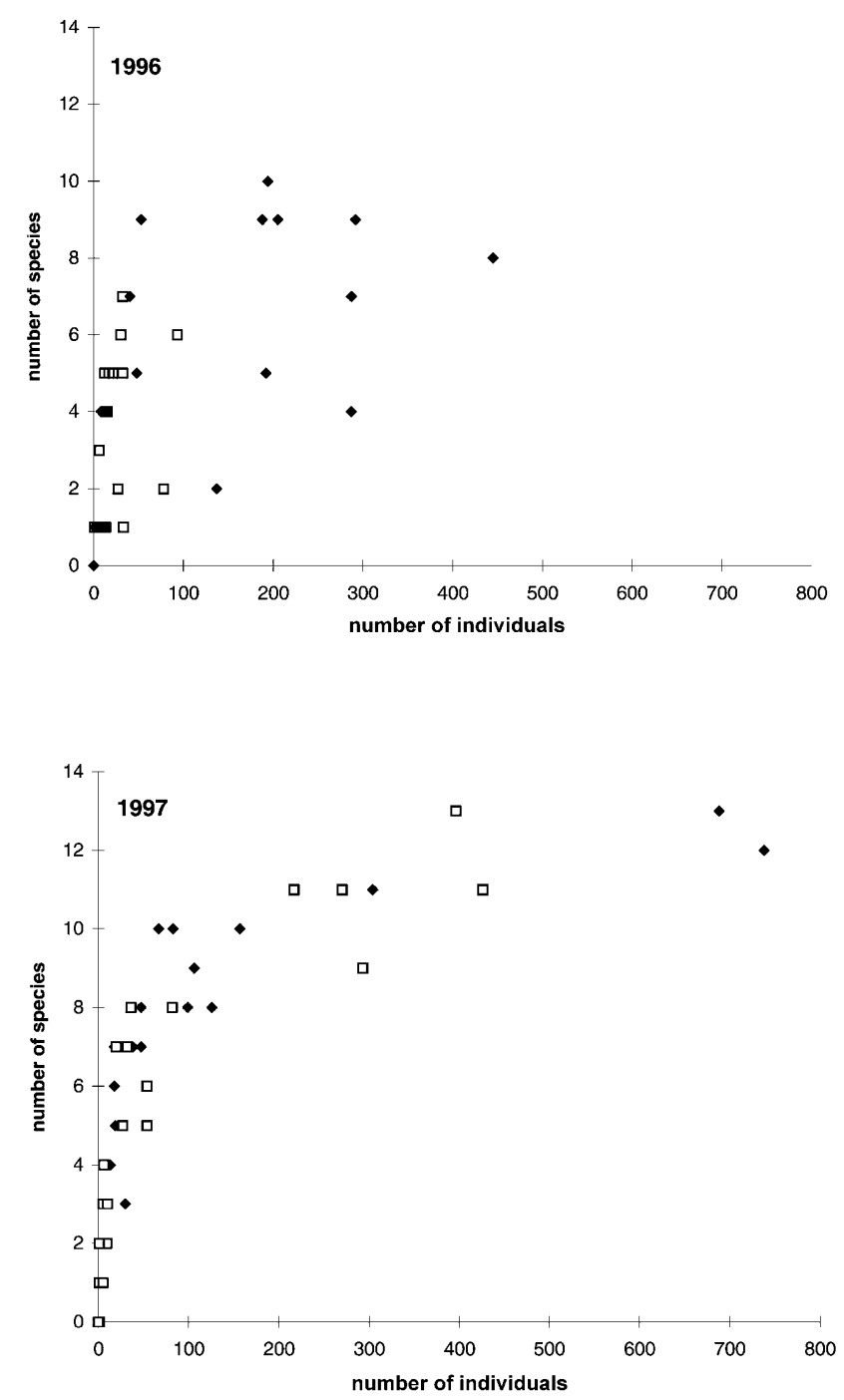

Fig. 3. Plot of individual number vs. species number for parasitoids in weekly Malaise catches from crop (filled symbols) and boundary (open symbols) in 1996 and 1997 (the two years with longest sampling periods in both habitats).

\section{Effect of harvesting on parasitoid catches}

At harvest the vegetation (crop) in the field was cut down, drastically altering the structure and conditions in this habitat. For most insects present, this disturbance must be expected to have a negative impact in general, and we predicted a decrease in the abundance of parasitoids after the harvest $\left(\mathrm{F}_{1} \mathrm{C}\right.$. fuscula was then long gone, escaping harvest by up to 4 weeks; Fig. 1). The boundary vegetation is left largely unaffected, so here we expected a concurrent increase in parasitoid catches (unless the harvesting killed them off).

We did observe a decrease in parasitoid abundance in the crop after harvesting, but this started well before harvest time: 5 and 2 weeks earlier, respectively, in the two years with crop trapping in the post harvest period (1996 and 1997). Coinciding with the decreasing numbers trapped in the crop, the boundary numbers increased (Spearman rank correlation of crop and boundary catches 
for the week when the catches peaked and the following 6 weeks: $r_{\mathrm{S}}=-0.72, \mathrm{p}=0.05$ for $1996 ; \mathrm{r}_{\mathrm{S}}=-0.85, \mathrm{p}=$ 0.006 for $1997 ; \mathrm{n}=7$ for both). Also in 3 of the 4 preceding years, the catches of parasitoids in the crop clearly started decreasing before harvesting, with a corresponding increase in the boundary (e.g. in 1993, see Fig. 1). A probable explanation of the above data is that parasitoids emerging from C. fuscula in the crop start to emigrate to/through the boundary as the barley plants ripen (i.e. dry out) and the probability of finding healthy (leaf mining) hosts decreases.

Thus, harvesting per se did not seem detrimental to the parasitoid population seen as a whole (consisting mainly of a few dominating species; Hågvar et al., 1998), since a large fraction had either died or left the crop by that time. However, since the number of parasitoid species increased until around harvesting in both habitats in most years, one cannot exclude the possibility that harvest disrupts the life cycle of late emerging species (Table 1), and indeed, may cause such species to be locally rare. Note that the number of parasitoids still present in the field at harvest time may be higher in this organically-grown field than in a conventional one, because more flowering weeds were present (e.g. Jervis et al., 1993) and because the field was undersown with clover which grew considerably after the barley was harvested. This could enhance parasitoid longevity, but could also delay departure to safer habitats. For parasitoids of the cabbage-worm, retention of post-harvest plants may be beneficial (Tscharntke, in press), but subsequent ploughing would kill parasitoids overwintering in the soil, as shown for parasitoids of rape pollen beetles (Nilsson, 1985) and the cereal leaf beetle (Tscharntke, in press). This would also be the fate of $C$. fuscula parasitoids trying to overwinter in a Norwegian cereal field (as adults or as preadults inside hosts).

Andersen (1999) found less attack by C. fuscula in crops with reduced tillage, compared with plants from tra-

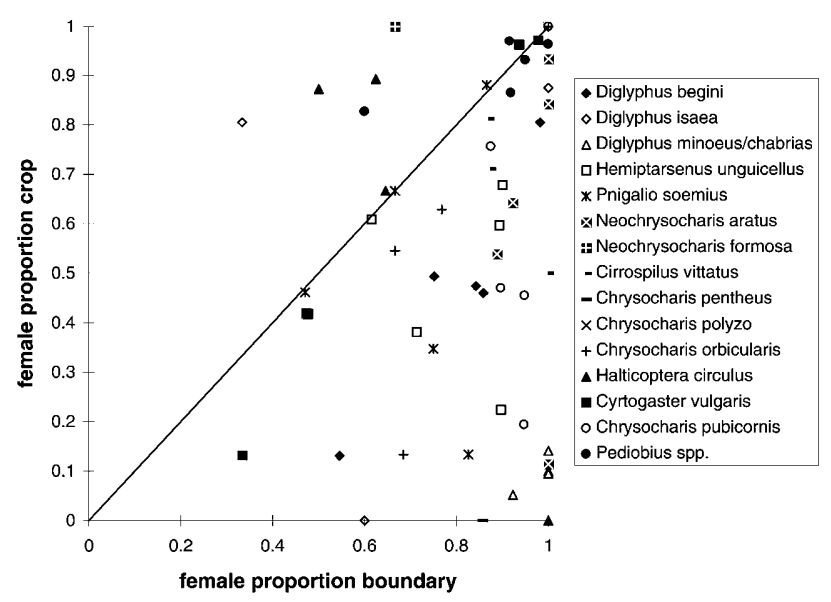

Fig. 4. Comparison of annual sex ratio (proportion females) in crop and boundary for 15 species of $C$. fuscula parasitoids. Each entry represents the pooled Malaise catch for one season of a species caught in both habitats that season. The line depicts equal female proportion in the two habitats. ditionally ploughed crops, and suggested that the latter plants were of better quality (i.e. were more suitable host plants). An alternative or additional explanation could be that reduced tillage is better for overwintering parasitoids than traditional ploughing.

\section{Annual sex ratio}

Studies on sex ratio in solitary parasitoids under field conditions are in general scarce. Apart from giving information on the biology and life cycle of particular parasitoids, which was our intention in the present study, such studies are important to supplement and test theoretical models and laboratory studies of sex allocation. Below, we discuss the sex ratio of the two most common species in our study in relation to their biology. Consideration of all species in each habitat first, however, yields an overall pattern (Fig. 4): annual catches from the boundary in general had a higher proportion of females than catches from the crop. In the boundary, the female proportion was nearly always above 0.5 (with two of the notable exceptions discussed below), while in the crop, the sex ratio varied more between years and species, being lower than 0.5 as often as higher.

The pattern of a higher female proportion in the boundary could be explained by sex-biased trapping, i.e. females having a higher relative probability of being trapped in the boundary than in the crop. This could happen if females were more active (or males less active) in the boundary than in the crop, or if there were an interaction between sex and habitat in preferred flying height. For example, Dyer \& Landis (1997) found by use of Malaise traps that males of Eriborus terebrans (Gravenhorst), a parasitoid of the European corn borer, fly higher than females (above $4 \mathrm{~m}$ ), and more so in the forest edge than in the corn field.

If our Malaise catches were unbiased, i.e. reflected true relative abundances, the boundary had a higher relative abundance of females than the crop. As discussed above, the majority of the trapped parasitoids probably belonged to the $F_{1}$ generation. The habitat may affect the $F_{1}$ sex ratio in two ways:

\section{(1) $F_{1}$ - females in the crop dispersing more than males}

The boundary may have qualities that make it relatively more attractive for females than males. Boundaries in general have alternative hosts, food resources for adults, favourable microclimate and shelter (e.g. Powell, 1986). Female parasitoids may live longer than males (Dyer \& Landis, 1996; Tscharntke, in press), and in any case they need food (sugar and pollen) for survival and future oviposition (Dyer \& Landis, 1997; Tscharntke, in press). Sex differences in migration pattern and habitat use have been found for some parasitoids in cornfields and in bean-corn intercrop (Coll \& Bottrell, 1996; Dyer \& Landis, 1997). In our barley field, as pointed out above in our discussion of the effect of harvest, the parasitoid catches decreased as the crop dried out, and we can envisage the following order of events to explain our data: $F_{1}$ parasitoids emerge from their hosts and mate in the crop, the females then move to a better habitat for host finding, foraging or over- 

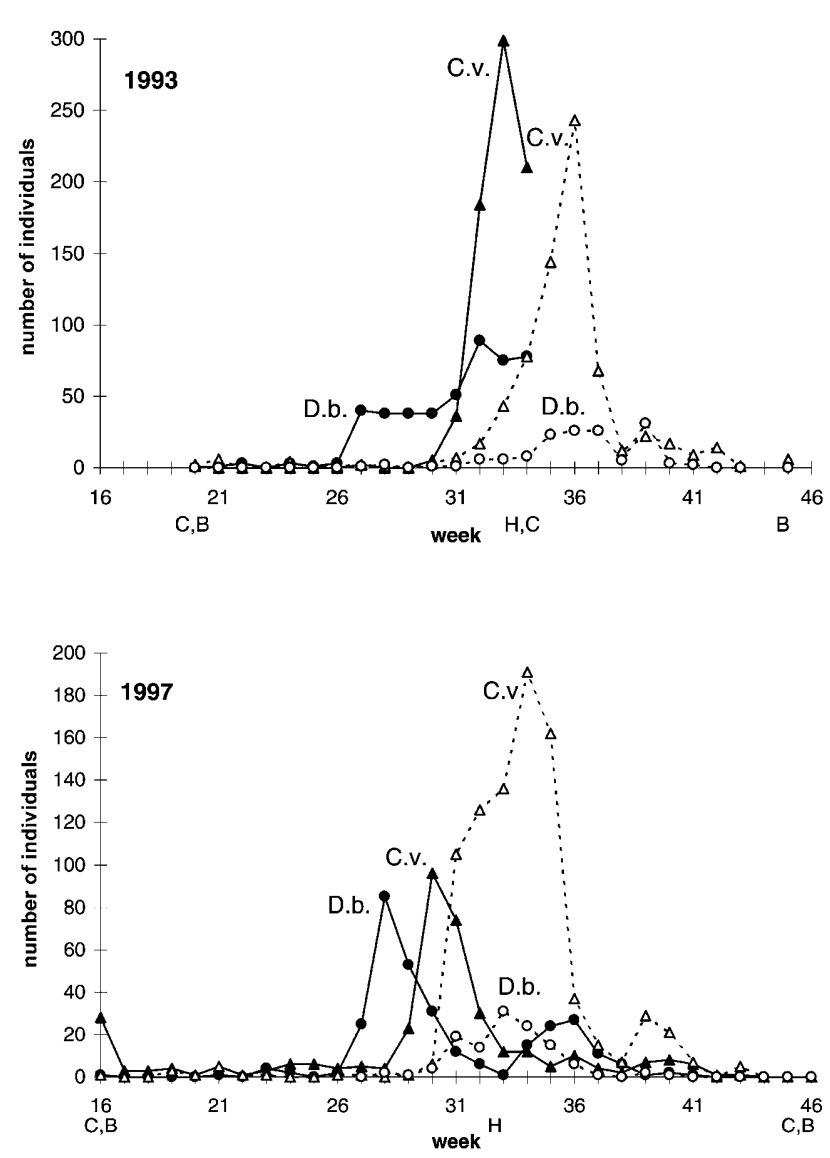

Fig. 5. Phenology of Malaise catches in crop (unbroken lines) and boundary (broken lines) for the parasitoids C. vulgaris (C.v.) and D. begini (D.b.) in 1993 and 1997. H - harvest; C crop trap put up or down; B - boundary trap put up or down. Note: $y$-axes vary in scale.

wintering, and the males die off after mating (without leaving the crop).

(2) $\mathrm{F}_{0}$ - females laying more fertilized eggs in the boundary than in the crop

If boundary catches mostly consisted of parasitoids that developed there (and not emigrants from the crop), the pattern could be the result of differential oviposition of fertilized eggs in the two habitats. This could be brought about by better host quality in the boundary than in the crop, or by sperm depletion in the crop. In a trap plant experiment in the same field, more females emerged from C. fuscula trap plants in the boundary than in the crop (Trandem, 1998).

These explanations are not mutually exclusive. Below, we return to some of them when discussing the two most common parasitoid species.

\section{Phenology and sex ratio of the two most common parasitoids}

The parasitoid patterns discussed above are the sum of different species with different biologies, as exemplified by the two most common species: Diglyphus begini (Eulophidae, a well-known specialist of agromyzid larvae, overwintering as preadult in the host mine) and Cyrtogaster vulgaris (Pteromalidae, a less-known polyphagous pupal parasitoid of Diptera and a facultative hyperparasitoid, overwintering as an adult). These two species together made up more than $50 \%$ of the annual catches (except in 1997, Hågvar et al., 1998), and below we will look at their phenology and sex ratio in some detail.

Diglyphus begini was present in the catches from April (crop) or May (boundary) to October (Table 1, Fig. 5). The species followed the general pattern with a more female-biased annual sex ratio in the boundary than in the crop (Fig. 4). The sex ratio was heavily male-biased in years with high emerging populations (Fig. 6). An ANCOVA model with habitat and annual catch of $D$. begini as variables explaining the annual female proportion was significant $\left(\mathrm{p}=0.03, \mathrm{~F}_{2,8}=6.1\right)$. However, this model was simplified, because both factors (habitat and density) were insignificant (see Crawley, 1993). Removing the least significant variable (habitat, $p=0.27$ ) produced a model with only significant parameters: Annual female proportion (arcsin-transformed) = 1.58- $0.16 \times$ Log annual number in catches (model statistics: $p=0.01, F_{1,9}=10.3$ ). Hence, the sex ratio in this species appears to be density dependent. In other words, $D$. begini seem to produce a male-biased sex ratio when they successfully parasitize a large host population (we did not directly measure the size of the larval $C$. fuscula population, but we did find a significant positive correlation between annual catches of $F_{0} C$. fuscula and $F_{1}$ parasitoids; Hågvar et al., 1998).

It is well documented in several solitary parasitoids that oviposition in small hosts gives rise to males and in large hosts to females (Godfray, 1994). This is the case for $D$. begini, where the ovipositing female chooses the sex of her offspring by interpreting host size on a relative scale (Heinz \& Parella, 1990b). However, it has been suggested

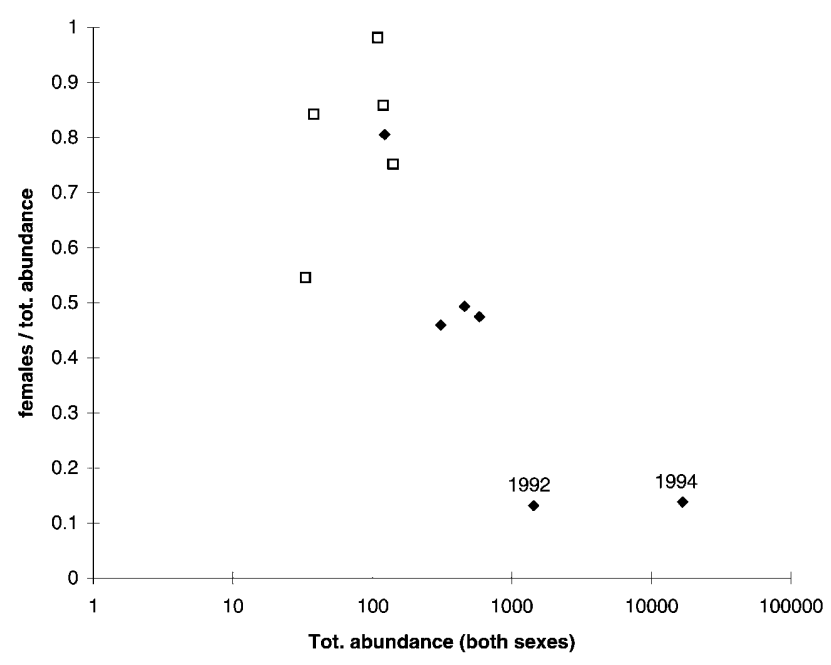

Fig. 6. Annual female proportion vs. total abundance of $D$. begini Malaise catches in the crop (filled symbols) and boundary (open symbols) 1992-1997. See text for statistics. 
that a male-biased sex ratio may be a common occurrence in Diglyphus, as demonstrated for D. begini in both laboratory cultures and glasshouse experiments, and from field collected $D$. isaea and $D$. intermedius producing heavily male-biased sex ratios (Heinz \& Parella, 1989, 1990a, b; Parrella et al., 1989; Heinz, 1991). If C. fuscula larvae are smaller when abundant (because of food competition; more than 20 mines can be present in one barley leaf), a higher proportion of parasitoid male eggs is expected. In addition, if relatively few parasitoid females are present in a large host population, sperm depletion may occur, with more male progeny as a result. We do not have data to distinguish between these possibilities in our study, and they are not mutually exclusive.

Both sexes of $D$. begini were present throughout the trapping period, although late samples mostly were females (Fig. 7). As expected, the $F_{1}$ generation of the larval parasitoid $D$. begini started to emerge before that of the pupal parasitoid C. vulgaris (Fig. 5). The following proposed life cycle accords with our data: $D$. begini overwinters as a larva or pupa in a host outside the crop (but not in the boundary habitat investigated here), the adults emerge in June and immigrate into the crop to oviposit in C. fuscula larvae. The $\mathrm{F}_{1}$ generation leaves the crop in July-August to find a host for overwintering. Surprisingly little data on the overwintering habits of this important species (it is commercially available as a biological control agent of agromyzid leaf miner pests) is found in the literature, but the finding of postfeeding, dormant larvae in C. fuscula mines from more northern parts of Norway indicates overwintering in this stage (Trandem, 1988). Questions remaining are which host species and habitats outside the crop are used by $D$. begini, and whether scarcity of such hosts limits the possibilities for control of $C$. fuscula.

Cyrtogaster vulgaris, the other parasitoid to be discussed here, makes an interesting contrast to $D$. begini. It was always present in the first catch each year (Table 1), and is the only species to occur in significant numbers before the distinct peak made by $F_{1}$ emergence (Fig. 5; see also Hågvar et al., 1998). It deviated from the overall annual sex ratio pattern reported above by being as variable in the boundary as in the crop, and by not having a consistently more female-biased ratio in the boundary than in the crop (Fig. 4). Consequently, its annual sex ratio could not be explained by habitat, nor by density $(\mathrm{p}=0.42$, $\mathrm{F}_{2,8}=0.96$; ANCOVA model with habitat and annual logtransformed $\mathrm{F}_{1}$ number of $C$. vulgaris as explanatory variables).

The phenology reported here (Figs 5, 7) is in accordance with the life cycle suggested by Askew (1965), who found that $C$. vulgaris in Britain overwinters as fertilized females and becomes active in early spring (see also Nedstam, 1985, 1987). These females are rather long lived (Trandem, unpubl.). Probably they disperse into the barley crop and parasitize C. fuscula pupae as soon as these occur in June/July. Males were scarcely caught early in the season, and did not appear in significant numbers until July (Fig. 7), when $F_{1}$ started to emerge.
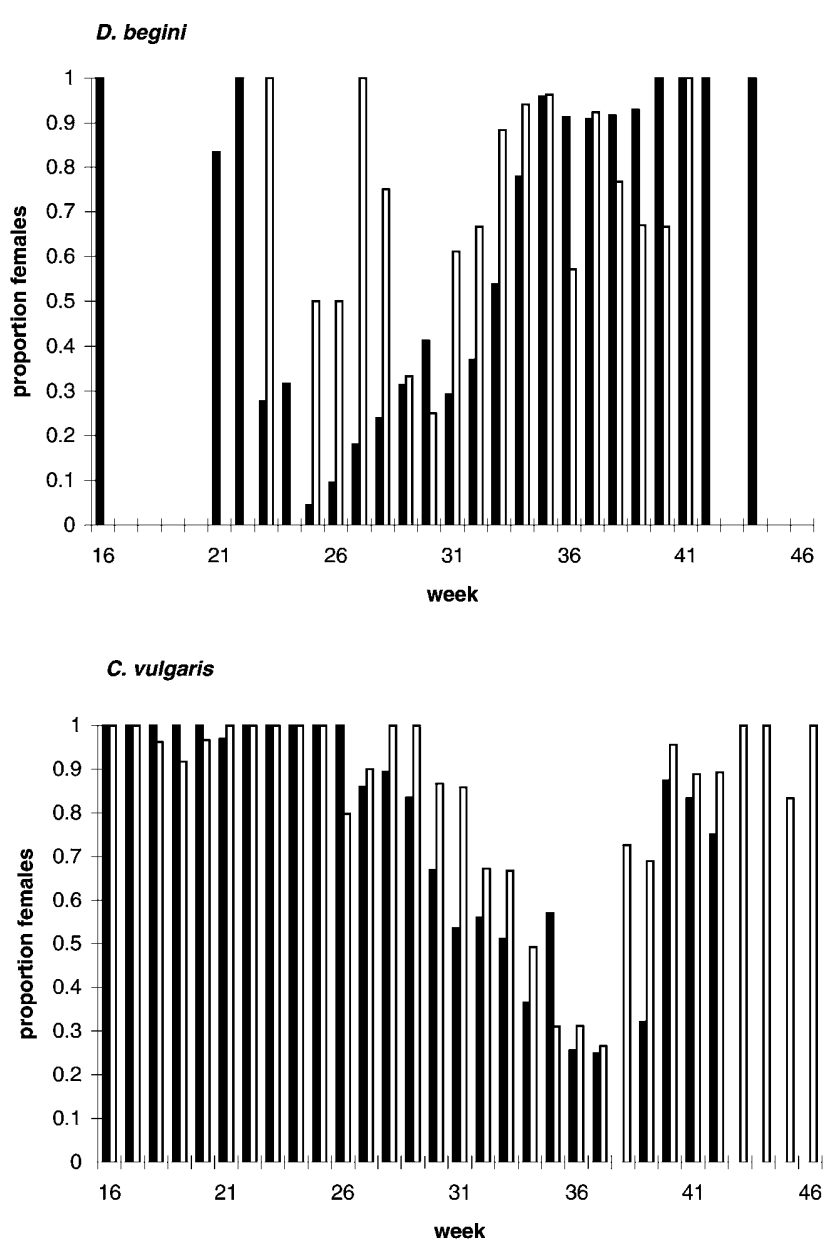

Fig. 7. Phenology of sex ratio (female proportion) in Malaise catches from crop (filled) and boundary (open) for the two most common parasitoids $D$. begini and $C$. vulgaris. Average of annual proportions (1992-97). The first and last column in $D$. begini represent only one female.

Mating must occur in the autumn, because very few males seem to survive the winter. Since the male proportions were as high in the boundary as in the crop, it is possible that the mating period is more prolonged than in the other species, with males emigrating from the crop together with the females. This, and the related fact that C. vulgaris always had a higher relative annual abundance in the boundary than in the crop (Table 2 in Hågvar et al., 1998), point to the boundary vegetation of our study as particularly important to this species, also as an overwintering habitat. Overwintering females have been found in emergence traps placed in the (grass) boundary of the study field in the spring (Trandem, unpubl.). Of the high numbers of $C$. vulgaris caught in an additional boundary trap in early spring 1996 (see Hågvar et al., 1998), 99\% were females. In Britain, Askew (1965) found overwintering females in very diverse places, from tree foliage to Carex turfs and hay stacks. It is important to note that the habit of adult overwintering frees this species from the constraint of having to find a suitable host for overwintering late in the season. This means that $C$. vulgaris in theory could sustain itself on the one genera- 
TABLE 1. Monthly presence ${ }^{1)}$ of Chromatomyia fuscula parasitoids in Malaise catches from a barley crop (C) and its boundary (B) 1992-1997. Species are presented in order of first appeareance.

\begin{tabular}{|c|c|c|c|c|c|c|c|c|c|}
\hline Parasitoid species & Habitat & & & & Mo & onth & & & \\
\hline Author & & Apr. & May & Jun. & Jul. & Aug. & Sep. & Oct. & Nov. \\
\hline $\begin{array}{l}\text { Cyrtogaster vulgaris } \\
\text { Walker }\end{array}$ & $\begin{array}{l}\mathrm{C} \\
\mathrm{B}\end{array}$ & $\begin{array}{l}\text { (5) } \\
\text { (5) }\end{array}$ & $\begin{array}{l}\text { (5) } \\
\text { (5) }\end{array}$ & $\begin{array}{l}\text { (5) } \\
(5)\end{array}$ & $\begin{array}{l}(5) \\
(5)\end{array}$ & $\begin{array}{l}(5) \\
(5)\end{array}$ & $\begin{array}{l}(5) \\
(5)\end{array}$ & $\begin{array}{l}\text { (5) } \\
\text { (5) }\end{array}$ & (4) \\
\hline $\begin{array}{l}\text { Diglyphus begini } \\
\text { (Ashmead) }\end{array}$ & $\begin{array}{l}\mathrm{C} \\
\mathrm{B}\end{array}$ & (5) & $\begin{array}{l}(4) \\
0\end{array}$ & $\begin{array}{l}(5) \\
0\end{array}$ & $\begin{array}{l}(5) \\
(5)\end{array}$ & $\begin{array}{l}(5) \\
\text { (5) }\end{array}$ & $\begin{array}{l}\text { (5) } \\
\text { (5) }\end{array}$ & $\begin{array}{l}\text { (5) } \\
\text { (2) }\end{array}$ & \\
\hline $\begin{array}{l}\text { D. isaea } \\
\text { (Walker) }\end{array}$ & $\begin{array}{l}\mathrm{C} \\
\mathrm{B}\end{array}$ & (5) & & (1) & (4) & (2) & $\begin{array}{l}\text { (2) } \\
\text { (2) }\end{array}$ & (2) & \\
\hline $\begin{array}{l}\text { Pnigalio soemius } \\
\text { (Walker) }\end{array}$ & $\begin{array}{l}\mathrm{C} \\
\mathrm{B}\end{array}$ & & (2) & $\begin{array}{l}\text { (5) } \\
\text { (3) }\end{array}$ & $\begin{array}{l}\text { (5) } \\
\text { (4) }\end{array}$ & $\begin{array}{l}\text { (5) } \\
\text { (4) }\end{array}$ & (2) & (2) & \\
\hline $\begin{array}{l}\text { D. minoeus/chabrias } \\
\text { (Walker) }\end{array}$ & $\begin{array}{l}\mathrm{C} \\
\mathrm{B}\end{array}$ & & 0 & $\begin{array}{l}(5) \\
0\end{array}$ & (5) & (5) & $\stackrel{\text { (2) }}{0}$ & & \\
\hline $\begin{array}{l}\text { Hemiptarsenus unguicellus } \\
\text { (Zetterstedt) }\end{array}$ & $\begin{array}{l}\mathrm{C} \\
\mathrm{B}\end{array}$ & & 0 & $\begin{array}{l}\text { (5) } \\
\text { (2) }\end{array}$ & $\begin{array}{l}(5) \\
(4)\end{array}$ & $\begin{array}{l}(5) \\
\text { (5) }\end{array}$ & $\begin{array}{l}(4) \\
\text { (5) }\end{array}$ & & \\
\hline $\begin{array}{l}\text { Neochrysocharis aratus } \\
\text { (Walker) }\end{array}$ & $\begin{array}{l}\mathrm{C} \\
\mathrm{B}\end{array}$ & & $\mathbb{1}$ & $\begin{array}{l}\text { (4) } \\
\text { (3) }\end{array}$ & $\begin{array}{l}(5) \\
(5)\end{array}$ & $\begin{array}{l}(5) \\
\text { (4) }\end{array}$ & 0 & & \\
\hline $\begin{array}{l}\text { Chrysocharis orbicularis } \\
\text { (Nees) }\end{array}$ & $\begin{array}{l}\mathrm{C} \\
\mathrm{B}\end{array}$ & & (2) & $\begin{array}{l}(5) \\
0\end{array}$ & $\begin{array}{l}(4) \\
\text { (2) }\end{array}$ & $\begin{array}{l}\text { (5) } \\
\text { (4) }\end{array}$ & (4) & (2) & \\
\hline Pediobius spp. ${ }^{2)}$ & $\begin{array}{l}\mathrm{C} \\
\mathrm{B}\end{array}$ & & & $\begin{array}{l}\text { (4) } \\
\text { (4) }\end{array}$ & $\begin{array}{l}(5) \\
(5)\end{array}$ & $\begin{array}{l}(5) \\
\text { (5) }\end{array}$ & $\begin{array}{l}(4) \\
\text { (4) }\end{array}$ & & \\
\hline $\begin{array}{l}\text { Chrysocharis pubicornis } \\
\text { (Zetterstedt) }\end{array}$ & $\begin{array}{l}\mathrm{C} \\
\mathrm{B}\end{array}$ & & & (3) & $\begin{array}{l}\text { (5) } \\
\text { (3) }\end{array}$ & $\begin{array}{l}\text { (5) } \\
\text { (4) }\end{array}$ & $\begin{array}{l}(4) \\
(4)\end{array}$ & $\begin{array}{l}\text { (3) } \\
\text { (2) }\end{array}$ & \\
\hline $\begin{array}{l}\text { Halticoptera circulus } \\
\text { (Walker) }\end{array}$ & $\begin{array}{l}\mathrm{C} \\
\mathrm{B}\end{array}$ & & & (3) & (5) & $\begin{array}{l}\text { (5) } \\
\text { (3) }\end{array}$ & $\begin{array}{l}\text { (4) } \\
\text { (4) }\end{array}$ & & \\
\hline $\begin{array}{l}\text { Cirrospilus vittatus } \\
\text { Walker }\end{array}$ & $\begin{array}{l}\mathrm{C} \\
\mathrm{B}\end{array}$ & & & $\begin{array}{l}\text { (3) } \\
0\end{array}$ & $\begin{array}{l}\text { (3) } \\
\text { (2) }\end{array}$ & (3) & (2) & $\begin{array}{l}\text { (3) } \\
\text { (2) }\end{array}$ & (2) \\
\hline $\begin{array}{l}\text { Chrysocharis pentheus } \\
\text { (Walker) }\end{array}$ & $\begin{array}{l}\mathrm{C} \\
\mathrm{B}\end{array}$ & & & 0 & (4) & (1) & 0 & (2) & \\
\hline $\begin{array}{l}\text { Neochrysocharis formosa } \\
\text { (Westwood) }\end{array}$ & $\begin{array}{l}\mathrm{C} \\
\mathrm{B}\end{array}$ & & & (1) & $\begin{array}{l}\text { (2) } \\
\text { (1) }\end{array}$ & (2) & & & \\
\hline $\begin{array}{l}\text { Chrysocharis polyzo } \\
\text { (Walker) }\end{array}$ & $\begin{array}{l}\mathrm{C} \\
\mathrm{B}\end{array}$ & & & & (3) & $\begin{array}{l}\text { (5) } \\
\text { (3) }\end{array}$ & $\begin{array}{l}\text { (4) } \\
\text { (3) }\end{array}$ & & \\
\hline $\begin{array}{l}\text { Mean No. of species } \\
\text { (No.of years trapping) }\end{array}$ & $\begin{array}{l}\mathrm{C} \\
\mathrm{B}\end{array}$ & $\begin{array}{l}3.0(1) \\
1.0(2)\end{array}$ & $\begin{array}{l}3.0(5) \\
2.0(5)\end{array}$ & $\begin{array}{l}8.5(6) \\
4.4(5)\end{array}$ & $\begin{array}{l}12.2(6) \\
8.2(5)\end{array}$ & $\begin{array}{l}11.5(6) \\
11.0(5)\end{array}$ & $\begin{array}{l}7.0(3) \\
8.6(5)\end{array}$ & $\begin{array}{l}3.0(2) \\
3.0(4)\end{array}$ & $\begin{array}{l}0(2) \\
1.0(3)\end{array}$ \\
\hline
\end{tabular}

1) Given as the percentage of years each species was found: $1=1-20 \% ; 2=21-40 \% ; 3=41-60 \% ; 4=61-80 \% ; 5=81-100 \%$. Years without trapping in that month excluded from the calculations. For accurate sampling periods: see Hăgvar et al. (1998).

2) P. epigonus group, mainly P. metallicus (Nees), see Hågvar et al. (1998) for details.

tion of C. fuscula pupae available each year, specializing on this abundant host. Regarding the question of whether C. vulgaris in practise has one or more generations, we have to conclude as Askew (1965): "(it) is not clear".

\section{CONCLUSIONS}

(1) The parasitoids of C. fuscula were active in crop and boundary for a longer period than their host. The main differences between these two habitats studied were: The crop had one or two peaks of the leafminer followed by a single parasitoid peak, while the boundary had few leafminers with no clear peaks, and parasitoids present throughout the season (with a peak in late summer). Thus, C. fuscula seems to use the boundary to a lesser extent than its parasitoids.

(2) The phenology of parasitoid abundance suggests that the majority of parasitoids starts to move from the crop to the boundary (or beyond) before harvesting. Har- vesting thus does not seem to harm the most common species which might be important control agents of the leaf miner.

(3) Parasitoid annual sex ratio was more female biased in the boundary than in the crop, and the phenology of the sex ratio suggests that females are more likely to emigrate from crop to boundary than males. The common $D$. begini seems to have a density dependent sex ratio.

(4) The importance of the boundary differed between parasitoid species, as exemplified by the two most common species: D. begini probably has one generation on C. fuscula and another one in an alternate host away from the habitats sampled here, where it overwinters inside the mine as a preadult. The near boundary thus seems unimportant for overwintering. In contrast, C. vulgaris overwinters as fertilized females, and the near boundary is likely to be important for the overwintering of this species. 
ACKNOWLEDGEMENTS. An anonymous referee gave very constructive comments. We thank C. Hansson and J. LaSalle for checking our parasitoid identifications, K.G. Sæterbøe, M. Singh, K.C. Hofmann, B. Dahlberg, M. Lund, and L. Fagerli for sorting the Malaise material, A. Andersen for information about C. fuscula, Ø. Kjos for practical help and advice, and the Research Council of Norway for financial support (E.H \& T.H. Project Nos 104011/110; E.H.: 114340/111; N.T.:103052/130).

\section{REFERENCES}

Altieri M.A. 1994: Biodiversity and Pest Management in Agroecosystems. Food Products Press, New York, 185 pp.

ANDERSEN A. 1991: Life-cycle of Chromatomyia fuscula (Zett.) (Dipt., Agromyzidae), a pest in Norwegian cereal fields. $J$. Appl. Entomol. 111: 190-196.

Andersen A. \& Fugleberg O. 1997: Development rates for Chromatomyia fuscula (Zett.) (Dipt., Agromyzidae) at five constant temperatures. J. Appl. Entomol. 121: 311-314.

ANDERSEN A. 1999: Plant protection in spring cereal production with reduced tillage. II. Pests and beneficial insects. Crop Prot. 18: 651-657.

Askew R.R. 1965: The holarctic species of Cyrtogaster Walker and Polycystus Westwood (Hym., Pteromalidae) including the description of a new species of Cyrtogaster from Britain. Entomophaga 10: 179-187.

Barbosa P. 1998: Conservation Biological Control. Academic Press, San Diego, 396 pp.

Coll M. \& Bottrell D.G. 1996: Movement of an insect parasitoid in simple and diverse plant assemblages. Ecol. Entomol.21: 141-149.

Crawley M.J. 1993: GLIM for Ecologists. Blackwell Scientific Publications, Oxford, $379 \mathrm{pp}$.

Darvas B., Andersen A. \& Thuroczy C. 1999: Generalist hymenopteran parasitoids of the leaf-miner Chromatomyia fuscula (Zett.) (Dipt.: Agromyzidae). J. Nat. Hist. 33: $1089-1105$

DYER L.E. \& LANDIS D.A. 1996: Effects of habitat, temperature, and sugar availability on longevity of Eriborus terebrans (Hymenoptera: Ichneumonidae). Envir. Entomol. 25: 1192-1201.

DYER L.E. \& LANDIS D.A. 1997: Influence of noncrop habitats on the distribution of Eriborus terebrans (Hymenoptera: Ichneumonidae) in cornfields. Envir. Entomol. 26: 924-932.

Eквом B., Irwin M.E. \& Robert Y. 2000: Interchanges of Insects Between Agricultural and Surrounding Landscapes. Kluwer Academic Publishers, Dordrecht, 239 pp.

Godfray H.C.J. 1994: Parasitoids. Behavioral and Evolutionary Ecology. Princeton University Press, New Jersey, 473 pp.

Hernz K.M. 1991: Sex-specific reproductive consequences of body size in the solitary ectoparasitoid, Diglyphus begini. Evolution 45: 1511-1515.

Heinz K.M. \& Parella M.P. 1989: Attack behavior and host size selction by Diglyphus begini on Liriomyza trifolii in chrysanthemum. Entomol. Exp. Appl. 53: 147-156.
Heinz K.M. \& Parella M.P. 1990a: Holarctic distribution of the leafminer parasitoid Diglyphus begini (Hymenoptera: Eulophidae) and notes on its life history attacking Liriomyza trifolii (Diptera: Agromyzidae) in Chrysanthemum. Ann. Entomol. Soc. Am. 83: 916-924.

Heintz K.M. \& Parella M.P. 1990b: The influence of host size on sex ratios in the parasitoid Diglyphus begini (Hymenoptera: Eulophidae). Ecol. Entomol.15: 391-399.

Hagvar E.B., Hofsvang T. \& Trandem N. 1994: The leafminer Chromatomyia fuscula (Diptera: Agromyzidae) and its parasitoid complex in Norwegian barley fields. In Hågvar E.B. \& Hofsvang T. (eds): Insect Parasitoids: Biology and Ecology. Proceedings from the 5th European Workshop on Insect Parasitoids, May 24-28, Biri, Norway. Norw. J. Agric. Sci. (Suppl. No. 16): 369-378.

Hagvar E.B., Hofsvang T., Trandem N. \& Seterbø K.G. 1998: Six-year Malaise trapping of the leaf miner Chromatomyia fuscula (Diptera: Agromyzidae) and its chalcidoid parasitoid complex in a barley field and its boundary. Eur. J. Entomol. 95: 529-543.

Jervis M.A., Kidd N.A.C., Fitton M.G., Huddleston T. \& DAWAH H.A. 1993: Flower visiting by hymenopteran parasitoids. J. Nat. Hist. 27: 67-105.

Parella M.P., Yost V.P., Heinz K.M. \& Ferrentino G.W. 1989: Mass-rearing of Diglyphus begini (Hymenoptra: Eulophidae) Girault, a parasite of Liriomyza spp. (Diptera: Agromyzidae). Envir. Entomol. 82: 420-425.

PowELL W. 1986: Enhancing parasitoid activity in crops. In Waage J. \& Greathead D. (eds): Insect Parasitoids. Academic Press, London, pp. 319-340.

Nedstam B. 1985: Development time of Liriomyza bryoniae Kalt. (Diptera: Agromyzidae) and two of its natural enemies, Dacnusa sibirica Telenga (Hymenoptera: Braconidae) and Cyrtogaster vulgaris Walker (Hymenoptera : Pteromalidae) at different constant temperatures. Med. Fac. Landbouww. Rijksuniv. Gent 50: 411-417.

Nedstam B. 1987: Biological control of Liriomyza bryoniae on tomato by Cyrtogaster vulgaris and Diglyphus isaea. OILB Bulletin 10: 129-133.

NILSSON C. 1985: Impact of ploughing on emergence of pollen beetle parasitoids after hibernation. Z. Ang. Entomol. 100: 302-308.

Trandem N. 1998: The Parasitoid Complex of the Leafminer Chromatomyia fuscula (Diptera: Agromyzidae) in Spring Barley. PhD Thesis, Agricultural University of Norway, As, $168 \mathrm{pp}$.

TscharntKe T. (in press): Parasitoid populations in the agricultural landscape. In Hochberg M.E. \& Ives A.R. (eds): Parasitoid Population Biology. Princeton University Press, New Jersey.

Revised MS received May 23, 2000; accepted June 26, 2000 